International Journal of Engineering \& Technology, 7 (4.30) (2018) 304-307
International Journal of Engineering \& Technology
SPC
Website: www.sciencepubco.com/index.php/IJET
Research paper

\title{
Review on Queueing Problem in Healthcare
}

\author{
Hajar Ariff ${ }^{1}$, M Ghazali Kamardan ${ }^{2 *}$, Suliadi Sufahani², Maselan Ali $^{3}$ \\ ${ }^{1,2,3}$ Department of Mathematic and Statistic, Faculty of Applied Science and Technology, Universiti Tun Hussein Onn Malaysia, Bandar \\ Universiti Edu Hub Pagoh, 84600 Pagoh, Johor, Malaysia. \\ *Corresponding author E-mail:mghazali@uthm.edu.my
}

\begin{abstract}
This article shows the application of queueing, simulation and scheduling used in the field of healthcare. A summary of queueing, simulation and scheduling theory used in waiting time, appointment system and patient flow are summarised in this article. Different departments in the healthcare system are also considered in this article such as emergency department, outpatient department and the pharmacy. The aim is to provide the reader a general background into queueing, simulation and scheduling in the healthcare.
\end{abstract}

Keywords: Healthcare; Scheduling; Simulation; Queueing.

\section{Introduction}

Patients are expected to receive treatment and services from specialized staff and equipment from the main healthcare facility centre which is the hospital. However, the queueing in many hospitals has been a big issue to the public. This is due to the long waiting time to receive health services. Furthermore, the very long waiting time for treatment results in boredom and can cause a patient's health status decline and hence, reduce the treatment efficiency due to patients may not be attended and end up going home without receiving attention.

The long waiting problem is caused by the increasing number of visitors and patients attending to the hospital while the services system remains unchanged. There are lot of complain has been reported due to queueing problem such as, lacking beds in the hospital, long queue at the pharmacy department and reduced number of equipment. The seriousness of this problem is often featured in the news report through the mainstream media.

In the hospital, the nurses, trained counter personnel including the IT staff and the entire equipment act as the servers in the queueing system while clients who come to the hospital include the walk-in patients, wait for the necessary service, obtain it and then leave upon completion of service or walk to another department expecting supplementary service [1].

\section{Queueing}

A study on the application of queueing theory and modelling to the queueing problem at the outpatient department at a hospital in Ghana is investigated. The method used are descriptive, observational and ex-post facto case study approach. The analysis came out with a result stated that optimum performance can be achieved with eight doctors compared to five doctors. Therefore, applying queuing theory and modelling to queueing can enhance decision making with regards to what will provide optimal performance [2]. As the solution to long waiting time, an efficient queuing model for proper appointment system is proposed. A series of interviews are carried out to get the general overview on the factors affecting patients waiting time. Hence, the appointment queueing system provides better utilization of resources and reduces patients waiting time in the outpatient department [1]. A survey on patient's satisfaction at the emergency department has been done which evaluated 2195 questionnaires for a period of three years to plan the capacity of emergency department in Mures, County, Romania to manage in optimal way to patient's flow. Queueing models are used to provide reasonable accurate evaluations for the system's performance and as a useful tool for decision making [3]. In this research, queueing theory has been used as the first tool to view patient waiting time on each server and the results show that the appointment system should be change for physicians. Through this research, recommendation on the best strategy to improve the appointment system and a study of the major causes of patients' length of time for medical treatment could be provided [4]. A descriptive analysis was conducted to develop a suitable model for determining waiting arrival time and service time of patients at the outpatient counter. This study included the arrival rate and service rate of patients at the outpatient counter for the analysis. The result shows that multiple server channel model was developed for the outpatient department with the focus on the patient waiting time to have the treatment [5].

\section{Simulation}

A simulation study to replicate patient movement flows in an emergency department (ED) of a general hospital in north Peninsular Malaysia has been conducted [6]. This study was carried out to evaluate resource utilization among personnel and physical resources. Then, a hybrid simulation method combining discrete event simulation and system dynamic modelling approach was proposed to better understand emergency department operations from a whole system perspective [7]. 
In this study, an improvement of discrete event simulation model for modelling outpatient pharmacy workflow queueing system has been done in an outpatient pharmacy in Riyadh. The intention of this study was to explore the possible options in designing efficient queueing system. The data were collected using stopwatch. Based on the analysis of the data which involved various scenarios, the result found from the simulation model shows that long waiting time exist in the system and simulation model basically helps to reduce the patients' waiting time and improve the service quality [8]. A suitable queueing theory and simulation technique has been developed in this study to optimize the management of studied outpatient pharmacy.

A descriptive analytical study was conducted with a sample of 220 patients involves in this study. The simulation results showed that reducing staff in the morning would not change the performance but increasing one staff may change the queue performance. Hence, by using queueing theory and simulation techniques, the patients' waiting time and number of waiting patients could be reduced [9]. In this research, a queueing model is developed using discrete event simulation where the healthcare centre at Mississippi State University (MSU) is selected as case example. The aim is to reduce patient waiting time and improve throughput the system. The results suggest that $50 \%$ of patients should follow normal route in the blood lab and another $50 \%$ should reroute to other lab [10]. In reducing average waiting time for outpatient section, a simulation for number of patients attending the outpatient section was simulated. Patient's arrival time, service time and average waiting time were calculated by simulating the number of patients. The results show that the average waiting time can be reduced by $40.97 \%$ if another doctor allocated to provide the services and the extra doctor must be present at least in the peak hours between 9 a.m. to 12 noon [11]

This study of [12] had proposed a new method for surgical scheduling which based on duration groups and level of variability for scheduled procedures in the operating theatres. A discrete event simulation was used to model and validate the daily surgical schedules. Based on the analysis, the result shows that how a can a method improves the surgery scheduling but additional factors such as considering accurate estimations for variability of surgeons and system for managing emergency should be included into the analysis [19-24].

\section{Scheduling}

In the research of [13] modelled the patients' flow using discrete event simulation where many appointment scheduling is analysed and evaluated with an attempt to address the appointment scheduling problem for appointment systems which involved multiple classes of patients having different mean service times, punctualities, no-show probabilities and service time variability. Thus, it is found that significant performance improvements may be achieved through classification and sequencing of patients [2527].

A research was developed to schedule the working shift of the nurses so that the availability and equality of the nurses were ensured. This research used goal programming method to develop the work shift schedule. The results show that the hard constraints were satisfied compared to the current scheduling work shift for the nurses in the hospital [14]. A real scheduling problem was used in this study to develop a mathematical model to schedule the operation theatre during peak and off-peak time. Integer Linear Programming and Linear Programming techniques were used for the analysis of this study. The results show that linear programming technique able to obtain optimal schedule which meet the aim to develop a mathematical model for the operation theatre scheduling and the related constraints [15]. A model was proposed for the scheduling entry of the non-critical patients into the Emergency Department which may be helpful for the management service. The data were extracted from the hospital historical data and the model was based on the patient scheduling algorithm. The results show that overall mean of $31 \%$ of the patient waiting time able to be reduced and proved that the model is efficient for the application within the service provided in the emergency department [16]. A mathematical programming model was proposed to generate physician schedules which satisfy physicians' preferences and their duty requirements. The constraints were collected and included into the analysis which results in the automated schedule provide fairness and more effective among the physicians [17].

In the research of [18], a stochastic integer programming was developed for multiple operating room to minimize the costs from both health care providers and patients. Synthetic data was used to test the performance of the proposed model and experiments were conducted to show the effectiveness of the proposed model. The results show that approximately $27 \%$ of the cost can be reduced by using the proposed stochastic integer programming model. The variables and constraints are introduced as follow:

$$
\sum_{t \in T} y_{i t} \leq 1 \forall i \in I, \quad y_{i t} \leq x_{t} \forall i \in I, t \in T
$$

$y_{i t} \in\{0,1\}, \forall i \in I, t \in T$, representing patient $i$ is assigned to the $t^{\text {th }}$ OR. The basic model includes:

Min

$$
\begin{aligned}
& \sum_{t \in T} c_{t} x_{t}+\sum_{t \in T} d_{i}\left(1-\sum_{t \in T} y i_{t}\right) \\
& +\sum_{k \in K} \sum_{T \in L} p_{I} q_{k}\left(\sum_{t \in T} W_{i} W_{i}^{k, l}+\sum_{t \in T} \text { Ot } O_{t}^{k, l}\right)
\end{aligned}
$$

\begin{tabular}{|c|c|c|c|}
\hline Author & Year & Title & Research Problem \\
\hline $\begin{array}{l}\text { Nor Aziati \& Nur } \\
\quad \text { Salsabilah }\end{array}$ & 2018 & $\begin{array}{l}\text { Application of Queueing Theory } \\
\text { Model and Simulation to Patient } \\
\text { Flow at The Outpatient Department }\end{array}$ & $\begin{array}{l}\text { To determine the waiting arrival time \& service time of patients at the outpatient } \\
\text { counter also to model suitable queueing system using simulation. } \\
\text { Arena student version unable to develop more than } 150 \text { entities waiting \& simulate } \\
\text { complex model. Only simple flow can be developed. }\end{array}$ \\
\hline Afrane \& Appah & 2014 & $\begin{array}{l}\text { Queueing Theory and The } \\
\text { Management of Waiting-time in } \\
\text { Hospitals: The Case of Anglo Gold } \\
\text { Ashanti Hospital in Ghana }\end{array}$ & $\begin{array}{l}\text { To investigate the application of queueing theory and modelling to the queueing } \\
\text { problem at the outpatient department at Anglogold Ashanti hospital in Obuasi, } \\
\text { Ghana. } \\
\text { This study however did not consider costs and it would be interesting to include the } \\
\text { cost dimension in another study in future. }\end{array}$ \\
\hline Obulor \& Eke & 2016 & $\begin{array}{lcr}\text { Outpatient } & \text { Queueing } & \text { Model } \\
\text { Development } & \text { for } & \text { Hospital } \\
\text { Appointment } & \text { System } & \end{array}$ & $\begin{array}{l}\text { To propose and efficient queueing model for proper appointment system as the } \\
\text { solution to the long waiting times. } \\
\text { Queueing model seems difficult to implement due to the increase in the calling } \\
\text { population. }\end{array}$ \\
\hline $\begin{array}{l}\text { Lade, Chowriwar } \\
\quad \& \text { Sawaitul }\end{array}$ & 2013 & $\begin{array}{l}\text { Simulation of Queueing Analysis in } \\
\text { Hospital }\end{array}$ & $\begin{array}{l}\text { To reduce the average waiting time of patients for OPD section. } \\
\text { There would be more profits made and more time to carry out business to improve }\end{array}$ \\
\hline
\end{tabular}

Table 1: Summary of Previous Study 


\begin{tabular}{|c|c|c|c|}
\hline & & & queues. \\
\hline Vass \& Szabo & 2015 & $\begin{array}{l}\text { Application of Queueing Model to } \\
\text { Patient Flow in Emergency } \\
\text { Department: Case Study }\end{array}$ & $\begin{array}{l}\text { To plan the capacity of ED situated in Mures County, Romania, to manage in } \\
\text { optimal way the patients flow using queueing model. } \\
\text { Models can be invaluable in providing decision support in complex environments } \\
\text { as the ED. }\end{array}$ \\
\hline $\begin{array}{l}\text { Hossain, } \\
\text { Khasawneh \& } \\
\text { Jaradat }\end{array}$ & 2017 & $\begin{array}{l}\text { Reducing Patient Waiting Time in } \\
\text { Outpatient Clinic: A Discrete Event } \\
\text { Simulation (DES) Based Approach }\end{array}$ & $\begin{array}{l}\text { To reduce patient waiting time and improve the overall throughput of the system. } \\
\text { Increasing rerouting of patients to lab technician may decrease the waiting time. }\end{array}$ \\
\hline Bahadori et al & 2014 & $\begin{array}{l}\text { Using Queuing Theory and } \\
\text { Simulation Model to Optimize } \\
\text { Hospital Pharmacy Performance }\end{array}$ & $\begin{array}{l}\text { To optimize the management of studied outpatient pharmacy by developing } \\
\text { suitable queueing theory and simulation technique. } \\
\text { The study has limitation where the over-the-counter drugs and patients requesting } \\
\text { such drugs were not considered in the evaluation of scenarios. }\end{array}$ \\
\hline $\begin{array}{l}\text { Alhaag, Aziz \& } \\
\text { Alharkan }\end{array}$ & 2015 & $\begin{array}{l}\text { A Queueing Model for HealthCare } \\
\text { Pharmacy Using Software Arena }\end{array}$ & $\begin{array}{l}\text { To improve and build a discrete event simulation model for modelling outpatient } \\
\text { pharmacy workflow queueing system with the intent of exploring options for } \\
\text { designing an efficient the queueing system of KKUH outpatient pharmacy Riyadh } \\
\text { KSA. } \\
\text { A flexible simulation model that can be applied into different type of systems and } \\
\text { able to give more accurate result should be developed. }\end{array}$ \\
\hline $\begin{array}{l}\text { Suliadi \& } \\
\text { Zuhaimy }\end{array}$ & 2014 & $\begin{array}{l}\text { A Real Scheduling Problem for } \\
\text { Hospital Operation Room }\end{array}$ & $\begin{array}{l}\text { To develop a mathematical model for scheduling the operating theatre during peak } \\
\text { and off-peak time. } \\
\text { Different approach can be used such as heuristic algorithm technique which able to } \\
\text { solve NP-hard scheduling problem for other related areas. }\end{array}$ \\
\hline $\begin{array}{l}\text { Nainggolan \& } \\
\text { Kusumastuti }\end{array}$ & 2017 & $\begin{array}{l}\text { Scheduling Nurses' Shifts at PGI } \\
\text { Cikini Hospital }\end{array}$ & $\begin{array}{l}\text { To identify nurse scheduling criteria and find the best schedule that can meet the } \\
\text { criteria. } \\
\text { Nurses should not be assumed to have similar level of skill and different nurses' } \\
\text { skills may be required in each shift. }\end{array}$ \\
\hline $\begin{array}{l}\text { Bruballa, Wong } \\
\quad \& \text { Epelde }\end{array}$ & 2017 & $\begin{array}{l}\text { Scheduling Model for Non-Critical } \\
\text { Patients Admission into a Hospital } \\
\text { Emergency Department }\end{array}$ & $\begin{array}{l}\text { To improve the quality of service in a ED, trying to reduce length of stay patients } \\
\text { in the service (LoS) through a model for scheduling the entry of non-critical } \\
\text { patients into the service. } \\
\text { Implementation of the proposed model in the real system should be noted to ensure } \\
\text { the effectiveness on the entry of patients, depends on the decision of the patients. }\end{array}$ \\
\hline $\begin{array}{l}\text { Shamia, } \\
\text { Aboushaqrah \& } \\
\text { Bayoumy }\end{array}$ & 2015 & $\begin{array}{l}\text { Physician On Call Scheduling: Case } \\
\text { of a Qatari Hospital }\end{array}$ & $\begin{array}{l}\text { To generate physician schedules that satisfy as may physicians' preferences and } \\
\text { duty requirements. } \\
\text { Both view from schedule maker and physician where hospital's policies, safety } \\
\text { regulations and high level of physician work life satisfaction should be included in } \\
\text { the schedule. }\end{array}$ \\
\hline Pang et al. & 2018 & $\begin{array}{l}\text { Surgery Scheduling under Case } \\
\text { Cancellation and Surgery Duration } \\
\text { Uncertainty }\end{array}$ & $\begin{array}{l}\text { To minimize the costs from the perspective of both health care providers and } \\
\text { patients by developing a stochastic integer programming model for multiple ORs } \\
\text { simultaneously considers the uncertainties of case cancellation and surgery } \\
\text { duration. } \\
\text { The model should be extended to a comprehensive scheduling system with both } \\
\text { elective and emergency surgeries included. }\end{array}$ \\
\hline $\begin{array}{l}\text { Schultz \& } \\
\text { Claudio }\end{array}$ & 2014 & $\begin{array}{l}\text { Variability } \quad \text { Based } \quad \text { Surgical } \\
\text { Scheduling: A Simulation Approach }\end{array}$ & $\begin{array}{l}\text { To propose a new methodology for surgical scheduling which sequences } \\
\text { procedures based on duration groups and their level of variability. } \\
\text { The model should consider the procedure variability to the scheduling problem for } \\
\text { the completion of more complex procedures. }\end{array}$ \\
\hline
\end{tabular}

\section{Discussion}

Table 1 shows the summary of previous study on the application of queueing, simulation and scheduling in healthcare. However, there is a few parts that need to be improved. Further contributions are listed in Table 2. Both scheduling and simulation can be implemented in queueing system. Scheduling helps in arranging and optimizing processes while simulation is an innovative approach to imitate the real-world operation process and improve system performance. Therefore, both scheduling and simulation are important to ensure queueing problem can be overcome based on what is the problem circumstances.

Table 2: Recommendations of the Research Contributions

\begin{tabular}{|ll|}
\hline \multicolumn{1}{c|}{ Contributions } \\
\hline i. & To analyse the current queuing problem in the healthcare. \\
ii. & To study the waiting times for the health services. \\
iii. & To simulate the healthcare system. \\
iv. & To validate the best decisions for the healthcare system. \\
v. & To reduce the waiting time during peak hour. \\
\hline
\end{tabular}

\section{Conclusion}

Queueing, simulation and scheduling are combinations of powerful management tool which often applied in many different areas which now has been applied in the medical sector. Proper implementation of these powerful management tool may lead to an effective and efficient management system.

\section{Acknowledgement}

Funding from U904 Tier 1.

\section{References}

[1] Obulor R \& BO Eke (2016), Outpatient Queueing Model Development for Hospital Appointment System. International Journal of Scientific Engineering and Applied Science (IJSEAS) 2(4), 15-22.

[2] Afrane S \& Appah A (2014), Queueing Theory and The Management of Waiting-time in Hospitals: The Case of Anglo 
Gold Ashanti Hospital in Ghana. International Journal of Academic Research in Business and Social Sciences 4 (2), 34-44.

[3] Vass H \& Szabo ZK (2015), Application of Queuing Model to Patient Flow in Emergency Department: Case Study. Procedia Economics and Finance 32, 479-487.

[4] Mardiah FP \& Basri MH (2013), The Analysis of Appointment System to Reduce Outpatient Waiting Time at Indonesia's Public Hospital. Human Resource Management Research 3(1), 27-33.

[5] Aziati AHN \& Salsabilah HN (2018), Application of Queueing Theory Model and Simulation to Patient Flow at The Outpatient Department. Proceedings of The International Conference on Industrial Engineering and Operations Management, 3016-3028.

[6] Ahmad N, Ghani NA, Kamil AA, Tahar RM (2015), Modelling the complexity of emergency department operations using hybrid simulation. Internat J. Simul. Process Model 10(4), 360-371.

[7] Laguna M \& Marklund J (2005), Business Process Modeling, Simulation and Design. Pearson Prentice Hall.

[8] Alhaag MH, Aziz T \& Alharkan IM (2015). A Queueing Model for Health Care Pharmacy using Software Arena. Proceedings of the 2015 International Conference on Industrial Engineering and Operations Management Dubai, United Arab Emirates (UAE).

[9] Bahadori M, Mohammadnejhad SM, Ravangard R \& E.Teymourzadeh (2014), Using Queueing Theory and Simulation Model to Optimize Hospital Pharmacy Performance. Iran Red Crescent Med J. 16(3), 1-7.

[10] Hossain NU, Khasawneh M \& Jaradat R (2017), Reducing Patient Waiting Time in an Outpatient Clinic: A Discrete Event Simulation (DES) Based Approach. Proceedings of the 2017 Industrial and Systems Engineering Conference.

[11] Lade IP, Chowriwar SA \& Sawaitul PB (2013), Simulation of Queueing Analysis in Hospital. International Journal of Mechanical Engineering and Robotics Research 2(3),122-128.

[12] Schultz J \& Claudio D (2014), Variability Based Surgical Scheduling: A Simulation Approach. Proceedings of The 2014 Winter Simulation Conference, 1353-1364.

[13] Bhattacharjee P \& Ray PK (2016), Simulation Modelling and Analysis of Appointment System Performance for Multiple Classes of Patients in a Hospital: A Case Study (8),71-84.

[14] Nainggolan JCT \& Kusumastuti RD (2018), Scheduling Nurses Shifts at PGI Cikini Hospital. IOP Conf. Series: Materials Science and Engineering 332, 1-7.

[15] Sufahani S \& Ismail Z (2014), A Real Scheduling Problem for Hospital Operation Room. Applied Mathematical Sciences 8(114), 5681-5688.

[16] Bruballa E, Wong A \& Epelde F (2017), Scheduling Model for Non-Critical Patients Admission into A Hospital Emergency Department. Proceedings of The 2017 Winter Simulation Conference, 2919-2928.

[17] Shamia O, Aboushaqrah N \& Bayoumy N (2015), Physician On Call Scheduling: Case of a Qatari Hospital. IEEE.

[18] Pang B, Xie X, Song Y \& Luo L (2018), Surgery Scheduling Under Case Cancellation and Surgery Duration Uncertainty. IEEE: Transactions on Automation Science and Engineering, 1-13.

[19] Jayeola D, Ismail Z, Sufahani SF \& Manliura DP (2017), Optimal method for investing on assets using black litterman model. Far East Journal of Mathematical Sciences 101(5), 1123-1131.

[20] Sufahani SF \& Ismail Z (2014), The statistical analysis of the prevalence of pneumonia for children age 12 in west Malaysian hospital. Applied Mathematical Sciences 8(113-116), 5673-5680.

[21] Sufahani SF, Che-Him N, Khamis A, Rusiman MS, Arbin NA C. K. Yee, I. N. Ramli, N. A. Suhaimi, S. S. Jing \& Z. A. Azmi, (2017), Descriptive statistics with box-jenkins and marketing research for jewellery company in Malaysia. Far East Journal of Mathematical Sciences 101(10), 2151-2161.

[22] Sufahani SF \& Ahmad A (2012), A comparison between normal and non-normal data in bootstrap. Applied Mathematical Sciences 6(89-92), 4547-4560.

[23] Rusiman MS, Hou OC, Abdullah AW, Sufahani SF \& Azmi NA (2017). An analysis of time series for the prediction of barramundi (Ikan Siakap) price in Malaysia. Far East Journal of Mathematical Sciences 102(9), 2081-2093.

[24] Ismail Z, Abu N \& Sufahani S (2016), "New product forecasting with limited or no data", AIP Conference Proceedings 1782 (050009).

[25] Kamardan MG, Sufahani S, Othman MZM, Che-Him N, Khalid K, Roslan R, Ali M \& Zaidi AMA (2018), A Mathematical Model
Development for the Lateral Collapse of Octagonal Tubes. Journal of Physics: Conference Series 995(1).

[26] Sufahani S, Kamardan MG, Rusiman MS, Mohamad M, Othman MZM, Khalid K, Ali M \& Nawawi MKM (2018), A Mathematical Study on additive Technique Versus branch and Bound Technique for Solving Binary Programming Problem. Journal of Physics: Conference Series 995(1).

[27] Kamardan MG, Aminudin N, Che-Him N, Sufahani S, Khalid K \& Roslan R (2018) Modified Multi Prime RSA Cryptosystem. Journal of Physics: Conference Series 995(1). 